\section{Germination of Nonstratified Japanese Tree Lilac Seeds as Influenced by Seed Capsule Maturity and Moisture Content}

\author{
Todd P. West ${ }^{1}$, Samuel L. DeMarais, and Chiwon W. Lee
}

AdDITIONAL INDEX wORDs. grafting, green seed, seed dormancy, Syringa reticulata

Summary. Temperate-zone woody plant species generally require seed stratification to overcome embryo dormancy. Embryo dormancy is variable in japanese tree lilac (Syringa reticulata) with a recommendation of 30- to 90-days stratification at 1-5 ${ }^{\circ} \mathrm{C}$. Cultivar propagation generally is done by grafting onto seedling rootstocks. It would be advantageous to rootstock seedling production to be able to reduce or eliminate the need for seed stratification to increase germination numbers as well as having production moved from field beds to greenhouses for quicker production of high-quality rootstock plants suitable for grafting. Research objective of this study was to determine if "green" seed could be used without the need of stratification for japanese tree lilac seedling production. Seed capsule fresh weight and seed moisture content were evaluated to determine if these factors could be used as predictors of germination percentages. Seed was randomly collected at the North Dakota State University campus in Fargo, ND, for seven consecutive weeks starting in Sept. 2011 and 2012. Germination and seed moisture tests were performed weekly. Germination percentage was highest $(89.5 \%)$ at week 2 and steadily decreased to $0 \%$ at week 7. Germination percentages were $77.5 \%, 89.5 \%, 78.5 \%, 67 \%, 24.5 \%, 1.5 \%$, and $0 \%$ for consecutive collection weeks $1-7$, respectively. Seed moisture content was $59.0 \%, 52.6 \%, 49.8 \%, 51.8 \%, 44.5 \%, 27.4 \%$, and $8.6 \%$ for collection weeks $1-7$, respectively. Germination percentage was directly correlated with seed moisture content and decreased as seed capsules matured (natural drying and splitting of capsule seem to disperse seed) during the fall season. Data suggest that timing of fall seed collection from japanese tree lilac is critical and must be done before maturation of the seed capsule to avoid the stratification requirement. Seed capsules with an average fresh weight higher than $0.2 \mathrm{~g}$ and seed moisture content greater than $50 \%$ produced the highest germination rates without requiring stratification.

$\mathrm{J}$ apanese tree lilac (Syringa reticulata) is a popular ornamental tree in the northern United States because of its flowering characteristics and its outstanding winterhardiness [U.S. Department of Agriculture hardiness zone 3-7 (USDA, 2012)] (Fig. 1A). Japanese tree lilac has a mature height of $8 \mathrm{~m}$ with a width approximately two-thirds of the mature height. Dirr (2009) reported that japanese tree lilac is possibly the most trouble-free lilac and is an excellent specimen and street tree. It bears large clusters of creamy white flowers in early summer and produces seed panicles, which have a slight ornamental appeal. Japanese tree lilac cultivars grown from seed are not true to parent and require clonal propagation for commercial production. Cultivars of japanese tree lilac are propagated either by stem cuttings,

Department of Plant Sciences, North Dakota State University, NDSU Department 7670, P.O. Box 6050, Fargo, ND 58108-6050

${ }^{1}$ Corresponding author. E-mail: todd.p.west@ndsu.edu. tissue culture, or grafting (Dirr and Heuser, 2006).

Grafting is generally performed on seedling rootstocks of japanese tree lilac. Commercial nurseries produce seedling rootstocks for grafting, which require stratification (moistchilling or moist-warm conditions) to overcome physiological or embryo dormancy. Seed dormancy is variable in japanese tree lilac with a recommendation of 40 - to $60-\mathrm{d} \operatorname{cool}\left(1-5^{\circ} \mathrm{C}\right)$ stratification (Hartmann et al., 2011). Shugert (1973) reported that fall planting of japanese tree lilac seed in Nebraska yielded 60\% to $65 \%$ germination rates without stratification. Unfortunately, there is no information reported on timing of seed collection or any other criteria for collection time to maximize germination rates without stratification (Shugert, 1973). Commercial nurseries in the northern United States sow stored dry seed in field beds in mid-July to produce a cotyledon or first true leaf seedling for overwintering with germination rates of $\approx 75 \%$ ( $\mathrm{N}$. Maren, personal communication). The following growing season, the seedlings are covered and uncovered to protect from early spring frosts. This frost prevention covering is often placed directly over the seedlings for insulation. The covering process often results in crooking of the seedling, making them unsalable for grafting use. It would be advantageous to rootstock seedling production if seed stratification can be eliminated to produce a sizable seedling that would not get seedling crooking from frost protection practices. This would allow for seedling production to be moved from field beds to greenhouses for quicker production of high-quality rootstock plants suitable for grafting.

There are three primary stages of seed development: stage I-embryo differentiation, stage II-cell expansion, and stage III-maturation drying (Hartmann et al., 2011). Hartmann et al. (2011) state that at the end of stage II the seed has reached physiological maturity and can be removed from the fruit without lowering germination rates. This process allows seed to be germinated without stratification. Japanese tree lilac seed capsules change color from green to yellow and finally brown before dehiscing. Japanese tree lilac seed is considered to be mature once seed capsule color change commences.

Research objective of this study was to determine if "green" seed could be used without the need of stratification for japanese tree lilac seedling production. Seed capsule fresh weight and seed moisture content were evaluated to determine if these factors could be used as predictors of germination percentages.

\begin{tabular}{llll}
\hline $\begin{array}{l}\text { Units } \\
\text { To convert U.S. to SI, } \\
\text { multiply by }\end{array}$ & U.S. unit & SI unit & $\begin{array}{l}\text { To convert SI to U.S., } \\
\text { multiply by }\end{array}$ \\
\hline 0.3048 & $\mathrm{ft}$ & $\mathrm{m}$ & 3.2808 \\
2.54 & inch $(\mathrm{es})$ & $\mathrm{cm}$ & 0.3937 \\
25.4 & inch $(\mathrm{es})$ & $\mathrm{mm}$ & 0.0394 \\
28.3495 & $\mathrm{oz}$ & $\mathrm{g}$ & 0.0353 \\
$\left({ }^{\circ} \mathrm{F}-32\right) \div 1.8$ & ${ }^{\circ} \mathrm{F}$ & ${ }^{\circ} \mathrm{C}$ & $\left({ }^{\circ} \mathrm{C} \times 1.8\right)+32$
\end{tabular}




\section{Materials and methods}

Seed Collection. Ripening or "green" seed was randomly collected from panicles (Fig. 1B) from five different japanese tree lilac trees on the North Dakota State University campus in Fargo, ND, each week, starting on 22 Sept., for 7 weeks $(22$ and 30 Sept.; 6, 13, 20, and 27 Oct.; 4 Nov.) in 2011. Start date for seed collection was determined based on capsule color. Seed capsules were collected just as the color began to fade from green to yellow (Fig. 1B). The seed from all five trees were randomly combined for use in this study. The seed moisture content data from 2011 was used to determine the collection starting date for 2012. Seed collected during week 1 in 2011 had seed moisture content of $58.4 \%$. Ripening seed was randomly collected from five different trees in 2012 for collection week 1 when seed moisture content reached $60 \%$. The 2012 season was more advanced than 2011 with seed collection beginning almost 2 weeks earlier (10, 17, and 24 Sept.; 1, 8, 15, and 22 Oct.) than 2011 . Seed capsule fresh weight was measured by sampling four replicates of 10 seed capsules from each weekly collection.

GERMinATION TEST AND SEED MOISTURE CONTENT. Seed germination and seed moisture content tests were performed at each seed collection. Seed used for germination and moisture content measurements was removed from the capsule by hand (Fig. 2). For the germination test, four replicates of 25 (total of 100 seeds) were planted each week in cell packs containing Sunshine ${ }^{\circledR}$ LCl (Sun Gro Horticulture Canada, Seba Beach, $\mathrm{AB}$, Canada) mix medium, placed under natural light conditions with air temperature of $21 \pm 3{ }^{\circ} \mathrm{C}$. All cell packs were hand-watered daily. Percent germination was based on the number of germinated seedlings after 4 weeks of greenhouse incubation.

Seed moisture content was measured by sampling four replicates of 10 seeds from each weekly collection. Each replicate was placed in a $100 \times$ $15-\mathrm{mm}$ glass petri dishes and placed in drying oven at $130{ }^{\circ} \mathrm{C}$ for $4 \mathrm{~h}$. Seedcoat rupturing was not required for drying because japanese tree lilac seed does not have a hard seedcoat requiring scarification. Seed moisture content was calculated by the

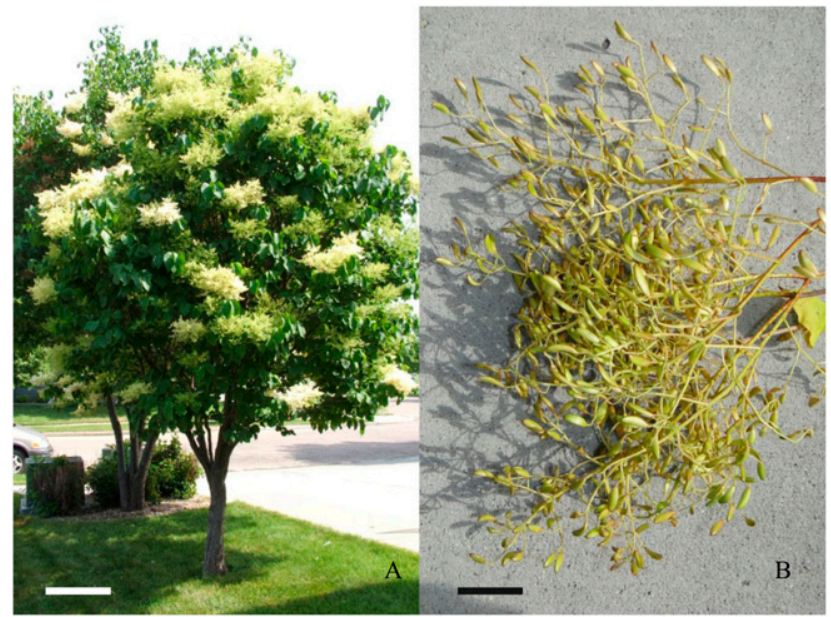

Fig. 1. (A) Japanese tree lilac in full bloom, bar $=0.5 \mathrm{~m}(1.64 \mathrm{ft})$. Photo: Greg Morgenson, NDSU. (B) Japanese tree lilac ripening seed capsules from pollinated inflorescence panicle, $b a r=5 \mathrm{~cm}(1.97 \mathrm{inch})$.

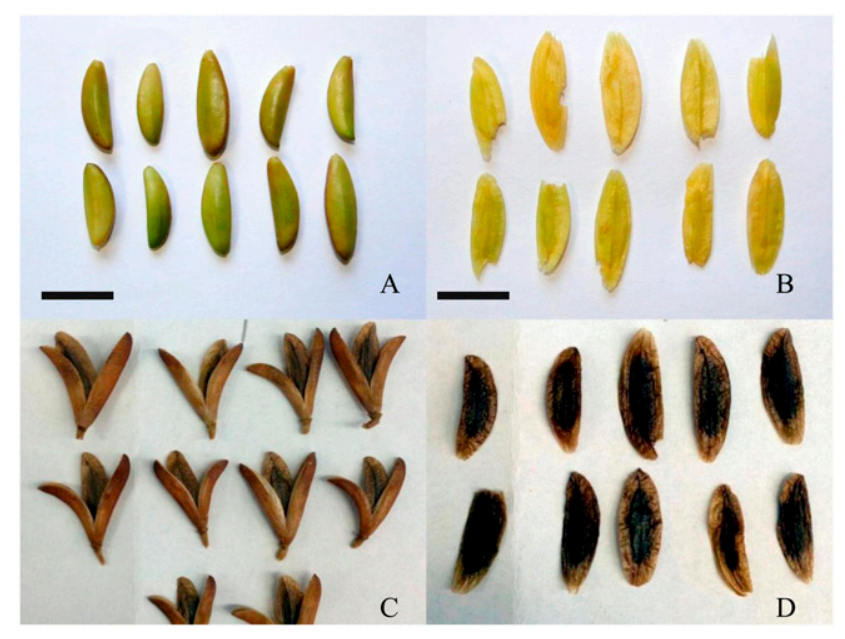

Fig. 2. Japanese tree lilac seed capsules and excised seed. (A) Nondehisced ripening "green" capsules collected 22 Sept. 2011, (B) excised ripening seeds from capsules collected 22 Sept. 2011, (C) dehisced capsules collected 4 Nov. 2011, and (D) excised seeds from capsules collected 4 Nov. 2011; bar $(A$ and C) $=1.5 \mathrm{~cm}$, bar (B and $\mathrm{D})=1 \mathrm{~cm} ; 1 \mathrm{~cm}=0.3937$ inch .

following equation: seed moisture content $=[$ seed fresh weight - seed dry weight $) /$ seed fresh weight $] \times 100$.

Data anAlysis. The analysis of variance procedure in SAS (version 9.3; SAS Institute, Cary, NC) was used to test for treatment effects. Means were separated by Duncan's multiple range test when a significant $(P \leq 0.05)$ difference occurred.

\section{Results and discussion}

Results indicate that japanese tree lilac seed can be germinated successfully without stratification if picked from "green" (nondried) capsules. This was also demonstrated with soybean (Glycine max) seeds, which had high viability and germination rates if seeds were removed from yellow pods before maturation drying of seeds in stage III (Miles et al., 1988). Similar responses were reported with showy lady's slipper orchid (Cypripedium reginae) and yellow lady's slipper orchid (C. parviflorum) in which seed germination decreased after pod and seed drying occurred during stage III seed development (De Pauw and Remphrey, 1993). There are limited examples of woody species reported with harvesting and growing out "green" seed. With american linden (Tilia americana), seed germination occurs in the second year after planting 
with standard late fall seed collection (Dirr and Heuser, 2006). American linden has been reported that early collection (generally September) of seed in Ontario, Canada, before seedcoat and wings turns from grey to brown will have increased germination without stratification (Leiss, 1985). Studies involving american linden at the Morden Research Station (Manitoba, Canada) indicate that $50 \%$ germination can result in early fall seed collection and sown immediately, there was no report on precise timing or other factors such as seed moisture content or seed fresh weight (Vanstone et al., 1982). This is the first report in japanese tree lilac of using "green" seed with measurement of seed moisture content and seed capsule fresh weight to determine harvest timing for propagation without stratification.

There was no significant difference between years 2011 and 2012, so data were combined for all further analysis. Japanese tree lilac seed yielded a reduction in seed moisture content with respect to collection dates averaged across 2011 and 2012 (Fig. 3). As the collection dates progressed into the two seasons, seed moisture decreased with a notable reduction occurring in week 6 . Seed moisture content was not a reliable indicator for seed collection that would yield the highest germination rates without stratification (Fig. 3).

Regarding germination rates, seed collected during week 2 (averaged across 2011 and 2012) yielded the highest germination rate $(89.5 \%)$ compared with other collection dates (Fig. 3). Percent germination increased from week 1 to week $2(77.5 \%$ to $89.5 \%)$, but then declined slightly from week 2 to week $3(89.5 \%$ to $78.5 \%)$, with a drop from week 4 to week 5 (67\% to $24.5 \%)$ (Fig. 3). De Pauw and Remphrey (1993) reported a reduction in germination rates $(62 \%$ to $18 \%$ ) of showy lady's slipper orchid grown on modified Norstog medium just 2 weeks after the highest germination rate.

Seed capsule fresh weight had a significant impact and is a clear indicator of germination rates. Seed capsules with average fresh weights higher than $0.2 \mathrm{~g}$ had the highest germination rates compared with lower fresh weights (Fig. 4). Higher seed capsule fresh weight was directly correlated to increased germination rates $\left(R^{2}=0.93777\right)$. Seed collected during week 2 (2011 and 2012) had the highest average capsule fresh weight and produced the highest average germination rate of $89.5 \%$ (Fig. 5). The seed capsules produced an increase in fresh weight from week

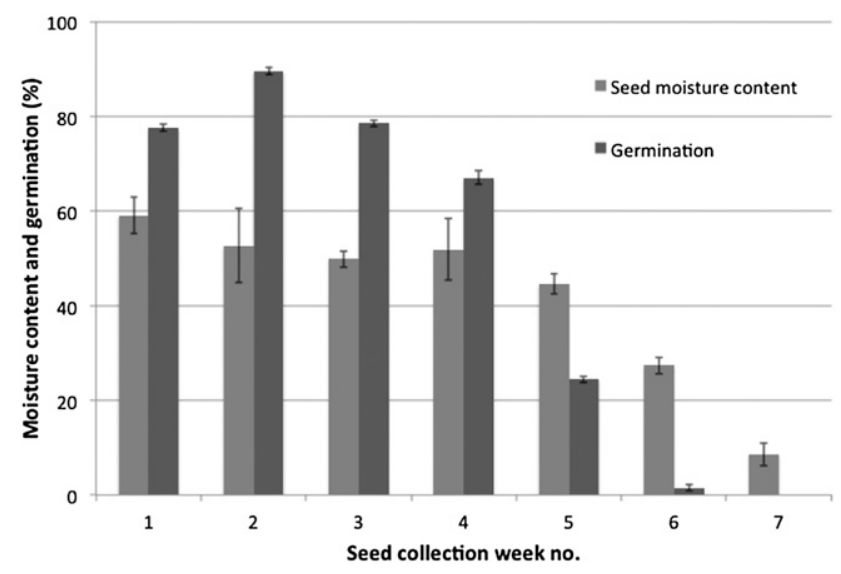

Fig. 3. Moisture content and germination of japanese tree lilac seed averaged from 2011 and 2012 collected over a 7-week (consecutive) harvesting period.

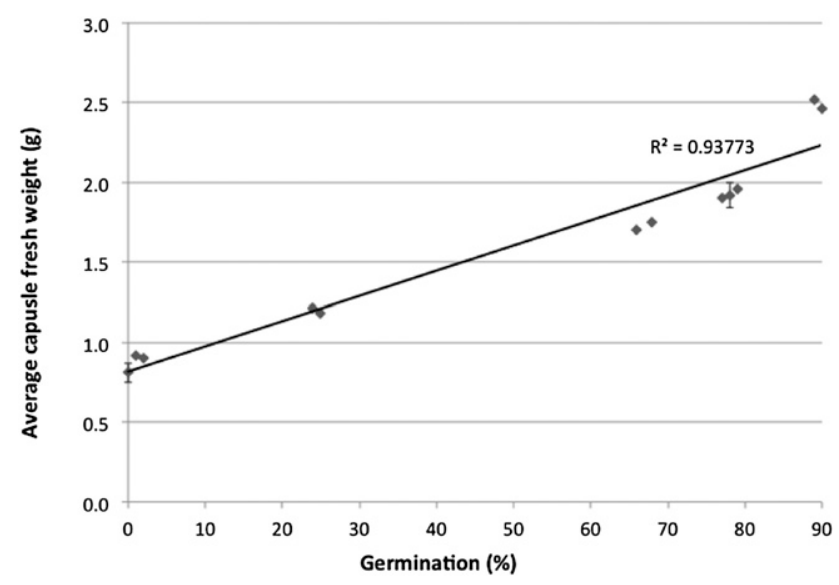

Fig. 4. Changes in average fresh capsule weight in relation to germination rates of japanese tree lilac seed harvested in 2011 and 2012. Capsule fresh weight is an average of 10 seed capsules $(P>F=0.0172) ; 1 \mathrm{~g}=0.0353 \mathrm{oz}$.

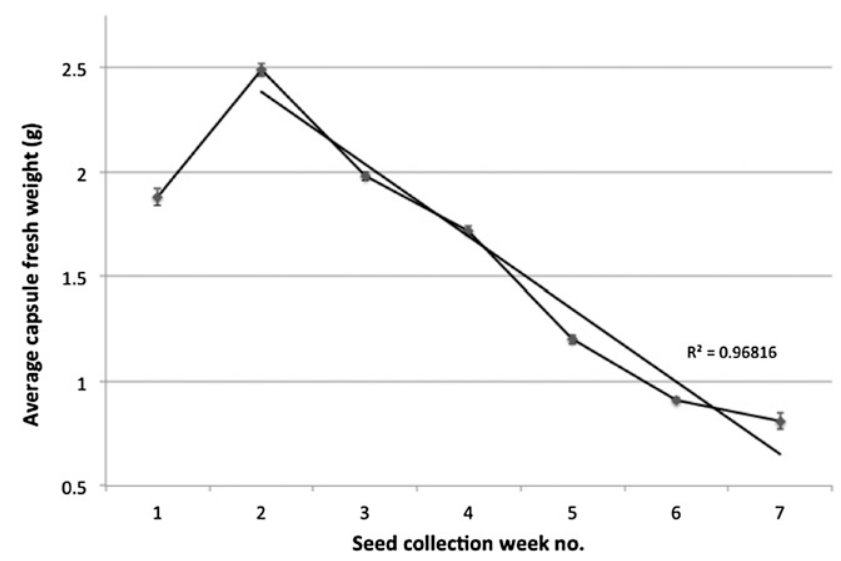

Fig. 5. Changes in average fresh capsule weight of japanese tree lilac seed as influenced by collection week in 2011 and 2012. Capsule weight is an average of 10 seed capsules $(P>F=0.0001)$. Linear regression represents decline in average capsule fresh weight from week 2 to 7 with week 1 omitted; $1 \mathrm{~g}=\mathbf{0 . 0 3 5 3} \mathrm{oz}$. 
1 to week 2 , followed by a decrease in fresh weight with each subsequent collection week. Seed moisture content was not a clear indicator of germination rates. The relationship of seed moisture content and germination percentage was compared with regression analysis $\left(R^{2}=0.76434\right)$ and found that seed moisture content was not a good indicator for germination rates in japanese tree lilac.

Seed capsule maturity had an impact on germination of "green" seed. As the capsule and seed naturally dried during stage III of seed development, germination significantly decreased. This process of drying prepares the seed for dormancy and subsequently requires stratification for germination.

\section{Conclusion}

Seed collected of japanese tree lilac from nondehisced ripening green capsules before natural drying were successfully germinated without requiring stratification. High germination percentages were directly correlated with high seed moisture content and decreased as seed capsule maturity progressed with natural drying and dehiscing of seeds. Seed capsule fresh weight was the most accurate indicator of seed germination. Seed capsules heavier than $0.2 \mathrm{~g}$ and seeds with moisture content greater than $50 \%$ produced the highest germination rates without requiring stratification. Data suggest that the timing of fall seed collection from japanese tree lilac is critical and that seeds must be harvested before seed capsule maturation, which precedes dormancy or the onset of embryo dormancy to avoid the 30 - to 90 -d seed stratification requirement.

The efficacy of using seeds collected before the normal harvesting time to enhance germination may well be applied to other woody ornamental species that require an extended period of seed stratification. In future studies, the relationship between time-dependent fluctuation and accumulation of inhibitor compounds in the embryo tissue may also be characterized in japanese tree lilac and other ornamental woody species.

\section{Literature cited}

De Pauw, M.A. and W.R. Remphrey. 1993. In vitro germination of three Cypridedium species in relation to time of seed collection, media, and cold treatment. Can. J. Bot. 71:879-885.
Dirr, M.A. 2009. Manual of woody landscape plants. 6th ed. Stipes Publ., Champaign, IL.

Dirr, M.A. and C.W. Heuser. 2006. The reference manual of woody plant propagation: From seed to tissue culture. 2nd ed. Timber Press, Portland, OR.

Hartmann, H.T., D.E. Kester, F.T. Davies, Jr., and R.L. Geneve. 2011. Plant propagation: Principles and practices. 8th ed. Prentice Hall, Upper Saddle River, NJ.

Leiss, J. 1985. Seed treatments to enhance germination. Intl. Plant Prop. Soc. Comb. Proc. 35:496.

Miles, D.F., D.M. TeKrony, and D.B. Egli. 1988. Changes in viability, germination, and respiration of freshly harvested soybean seed during development. Crop Sci. 28:700-704.

Shugert, R. 1973. Propagators potpourri. Intl. Plant Prop. Soc. Comb. Proc. 23:359.

U.S. Department of Agriculture. 2012. USDA plant hardiness zone map. 5 Feb. 2014. <http://planthardiness.ars.usda. gov $/ \mathrm{PHZMWeb} />$.

Vanstone, D.E., W.G. Ronald, and H.H. Marshall. 1982. Nursery propagation of woody and herbaceous perennials for the prairie provinces. Agr. Can. Publ. 1733E. 